DOI: $10.20961 /$ jpscr.v3i2.21796

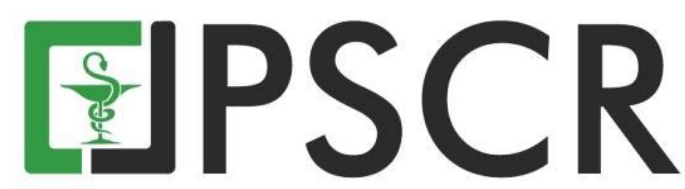

\title{
Pengaruh Pemberian Ekstrak Daun Karika (Vasconcellea pubescens A.DC.) Terhadap Nilai SGPT dan SGOT pada Tikus Jantan yang Diinduksi Parasetamol
}

\author{
Heru Sasongko $^{1 *}$ dan Sugiyarto ${ }^{2}$ \\ ${ }^{1}$ Program Studi S1 Farmasi, Fakultas Matematika dan Ilmu Pengetahuan Alam, Universitas Sebelas Maret \\ 2 Program Studi S1 Biologi, Fakultas Matematika dan Ilmu Pengetahuan Alam, Universitas Sebelas Maret \\ *email korespondensi : heru_sasongko@staff.uns.ac.id
}

\begin{abstract}
Abstrak: Parasetamol merupakan salah satu antipiretik yang sudah terbukti bisa menyebabkan kerusakan hati pada penggunaan dosis toksik. Kenaikan nilai SGPT (Serum Glutamat Piruvat Transaminase) dan SGOT (Serum Glutamat Oksaloasetat Transaminase) merupakan salah satu parameter adanya gangguan fungsi hati. Pemberian suatu antioksidan dilaporkan berpengaruh terhadap proteksi kerusakan fungsi hati. Daun karika (Vasconcellea pubescens A.DC.) pada penelitian sebelumnya telah diketahui dapat berperan sebagai antioksidan. Tujuan dari penelitian ini adalah untuk mengetahui pengaruh pemberian ekstrak etanol daun karika terhadap nilai SGPT dan SGOT pada model tikus yang diinduksi parasetamol. Pengujian dilakukan selama 9 hari terhadap 30 ekor tikus jantan galur Sprague Dawley (150-200 g, 2-3 bulan) yang diacak menjadi 6 kelompok. Kelompok I sebagai kontrol normal, kelompok II diberi CMC Na 0,5\% (p.o) sebagai kontrol negatif, kelompok III diberi silimarin dosis $100 \mathrm{mg} / \mathrm{kgBB}$ (p.o) sebagai kontrol positif, dan kelompok IV-VI diberi ekstrak etanol daun karika dengan dosis 60, 120, dan 240 $\mathrm{mg} / \mathrm{kgBB}$ (p.o). Induksi parasetamol dosis $2 \mathrm{~g} / \mathrm{kg}$ BB dilakukan pada hari ke-7. Serum darah diambil pada hari ke-9 untuk diukur kadar SGPT dan SGOT. Data kemudian dianalisis secara statistik menggunakan ANOVA. Hasil pengujian menunjukkan bahwa ekstrak etanol daun karika mulai dosis $60 \mathrm{mg} / \mathrm{kgBB}$ dapat menurunkan kadar SGPT dengan kadar 240,846 $\pm 11,15 \mathrm{U} / \mathrm{I}$ $(\mathrm{p}<0,05)$ dan SGOT dengan kadar 742,632 $\pm 68,81 \mathrm{U} / \mathrm{I}(\mathrm{p}<0,05)$. Semua dosis ekstrak mampu menurunkan kadar SGPT dan SGOT secara signifikan bila dibandingkan dengan kontrol negatif. Pemberian ekstrak etanol daun karika berpengaruh pada penurunan kadar SGPT dan SGOT pada tikus jantan galur Sprague Dawley yang diinduksi parasetamol.
\end{abstract}

Kata kunci: Karika; Hepatoprotektor; Parasetamol; SGPT; SGOT

Abstract. Effect of Carica (Vasconcellea pubescens A.DC.) leaves extract on the level of SGPT and SGOT in paracetamol-induced male rats. Paracetamol is one of the antipyretic drugs that is known can cause liver damage in the toxic dose. The increase of Serum Glutamic Pyruvic Transaminase (SGPT) and Serum Glutamate Oxaloacetate Transaminase (SGOT) values are the parameters of liver injury. The antioxidant can help protect liver from injury. Carica or mountain papaya (Vasconcellea pubescens A.DC.) leaves in previous studies have been known to act as antioxidants. This research aims to know the effect of ethanolic extract of carica leaves on SGPT and SGOT levels on paracetamol-induced male rat. The test were conducted for nine days against 30 male Sprague Dawley rats (150-200 g, 2-3 months). The rat divided into six groups randomly. Group I as normal control, group II was given $0.5 \% \mathrm{CMC} \mathrm{Na} \mathrm{(p.o)} \mathrm{as} \mathrm{negative}$ 
control, group III was given $100 \mathrm{mg} / \mathrm{kg}$ b.w (p.o) silymarin as positive control, and group IV-VI was given extract with dose 60,120, and $240 \mathrm{mg} / \mathrm{kg} \mathrm{b.w} \mathrm{(p.o)} \mathrm{respectively.} \mathrm{The} \mathrm{dose} 2 \mathrm{~g} / \mathrm{kg} \mathrm{b.w}$ of paracetamol was given on day 7. Blood serum was taken on day 9 for measuring levels of SGPT and SGOT. The data were statistically analyzed using ANOVA. The results showed that the ethanolic extract of carica leaves starting at a dose of $60 \mathrm{mg} / \mathrm{kg}$ b.w could reduce levels of SGPT with levels of $240.846 \pm 11.15$ U/I $(\mathrm{p}<0.05)$ and SGOT with levels of $742.632 \pm 68.81$ $\mathrm{U} / \mathrm{I}(\mathrm{p}<0.05)$. All extract doses can significantly reduce SGPT and SGOT levels compared to negative controls. Ethanolic extract of carica leaves can decrease of SGPT and SGOT levels in male Sprague Dawley rats induced by paracetamol.

Keywords: Mountain papaya; Hepatoprotective; Paracetamol; SGPT; SGOT

\section{Pendahuluan}

Obat merupakan salah satu penyebab kerusakan hati yang menjadi kekhawatiran bagi pasien dan tenaga kesehatan (Chen et al., 2015). Reaksi idiosinkrasi, penggunaan obat dengan dosis berlebih dan jangka panjang merupakan penyebab utama kasus kerusakan hati dan berujung proses transplantasi (Reuben et al., 2010). Parasetamol merupakan salah satu obat analgesik dan antipiretik yang bisa menyebabkan kerusakan hati (Larsen dan Wendon, 2014). Hal ini dapat terjadi karena parasetamol yang termetabolisme dalam hati membentuk metabolit n-acetyl-p-benzoquinoneimine (NAPQI) yang reaktif dan berinteraksi secara kovalen dengan makromolekul hati pada bagian sistein yang mengakibatkan terjadinya stres oksidatif (Brune et al., 2015; Vakiloddin et al., 2015). Serangkaian reaksi tersebut kemudian disinyalir menyebabkan kerusakan hati (James et al., 2003). Kenaikan kadar serum glutamat piruvat transaminase (SGPT) dan serum glutamat oksaloasetat transaminase (SGOT) adalah parameter spesifik terjadinya kerusakan fungsi hati khususnya SGPT (Gowda et al., 2009). Untuk mengatasi kejadian kerusakan fungsi hati telah dilakukan banyak penelitian yang menghubungkan antara aktivitas antioksidan dengan suatu hepatoprotektor (Chiu et al., 2003; Jain et al., 2008; Videla, 2009).

Karika (Vasconcellea pubescens A.DC.) merupakan tumbuhan yang termasuk dalam familia Caricaceae dan satu genus dengan Carica papaya (Laily et al., 2012). Tanaman ini sekilas tampak seperti pepaya akan tetapi memiliki karakter khusus yaitu pada daun bagian bawah, tangkai daun, dan permukaan luar bunga dipenuhi bulu (Supono, 2014). Daun karika (Vasconcellea pubescens A.DC.) diketahui mengandung beberapa metabolit sekunder seperti flavonoid, alkaloid, tannin dan fenol yang berkhasiat sebagai antioksidan (Mu'awwanah dan Ulfah, 2017; Novalina, 2013). Tujuan dari penelitian ini adalah untuk mengetahui ada tidaknya pengaruh pemberian ekstrak etanol daun karika terhadap kadar SGPT dan SGOT pada tikus jantan galur Sprague Dawley yang diinduksi parasetamol dosis akut. 


\section{Bahan dan Metode}

\subsection{Alat dan bahan}

Alat-alat yang digunakan meliputi neraca analitik (Ohaus), oven (Memmet), rotary evaporator (Stuart RE300), Spektrofotometer (Shimadzu). Bahan-bahan berupa daun karika dari lereng Pegunungan Lawu Karanganyar, etanol 70\% (teknis), aquades, silimarin (Sigma-Aldrich), reagen SGPT (Diasys), reagen SGOT (Diasys) dan paracetamol (Kimia Farma).

\subsection{Pembuatan simplisia dan ekstraksi}

Proses pembuatan simplisia dan proses ekstraksi mengikuti penelitian sebelumnya yang dilakukan oleh Sasongko et al. (2016).

\subsection{Penyiapan hewan uji}

Penelitian ini menggunakan 30 ekor tikus putih jantan galur Sprague Dawley dengan usia 2-3 bulan dan berat 150-200 g. Sebelum perlakuan, tikus diadaptasikan selama 7 hari dan diberi makan minum standar.

\subsection{Pengelompokan dan perlakuan hewan uji}

Sebanyak 30 ekor tikus dibagi acak dalam 6 kelompok masing-masing sebanyak 5 ekor. Kelompok I merupakan kelompok kontrol normal dan hanya diberi makan dan minum standar. Kelompok II merupakan kelompok kontrol negatif dan diberikan suspensi CMC Na 0,5\% b/v 1 mL. Kelompok III merupakan kelompok kontrol positif dan diberikan silimarin dosis $100 \mathrm{mg} / \mathrm{kg}$ BB. Kelompok IV-VI diberikan ekstrak etanol daun karika masing - masing dengan dosis 60, 120, dan $240 \mathrm{mg} / \mathrm{kg}$ BB. Pengujian dilakukan selama 9 hari dan induksi parasetamol dosis 2 g/kg BB dilakukan pada hari ke-7 pada 30 menit setelah pemberian sampel uji. Serum darah diambil pada hari ke-9 untuk diukur kadar SGPT dan SGOT.

\subsection{Pengukuran kadar SGPT dan SGOT}

Kadar SGPT dan SGOT diukur berdasarkan reaksi enzimatik menggunakan reagen SGPT dan reagen SGOT mengikuti prosedur yang dilakukan oleh Nurrochmad et al. (2013).

\subsection{Analisis data}

Data terkumpul kemudian dianalisis secara statistik. Tes Kolmogorov-Smirnov untuk mengetahui distribusi data dilanjutkan uji homogenitas kemudian uji ANOVA (Analysis of 
Variance) dan Post Hoc Test dengan $\mathrm{p}<0,05$ untuk mengetahui ada tidaknya perbedaan antar kelompok.

\section{Hasil dan Pembahasan}

Proses ekstraksi daun karika didapatkan rendemen sebesar 15,20\% dari berat simplisia kering $1 \mathrm{~kg}$. Hasil pengukuran kadar SGPT dan SGOT pada tikus setelah diinduksi parasetamol dengan pemberian ekstrak daun karika dapat dilihat pada tabel I. Tabel I menunjukkan terdapat perbedaan kadar SGPT dan SGOT pada hati tikus yang mendapatkan ekstrak daun karika dan silimarin dibandingkan dengan kontrol negatif $(\mathrm{p}<0.05)$.

Tabel 1. Kadar SGPT dan SGOT pada serum darah tikus yang telah diinduksi parasetamol dengan pemberian ekstrak daun karika. Tanda asterisk (*) merupakan nilai yang berbeda bermakna melalui uji Post Hoc (LSD) terhadap kontrol negatif pada taraf kepercayaan $95 \%$

\begin{tabular}{lcc}
\hline \multicolumn{1}{c}{$\begin{array}{c}\text { Kelompok } \\
(\mathrm{n}=5 \text { ekor/ kelompok) }\end{array}$} & $\begin{array}{c}\text { SGPT } \pm \text { SD } \\
\text { U/I }\end{array}$ & $\begin{array}{c}\text { SGOT } \pm \text { SD } \\
\text { U/l }\end{array}$ \\
\hline Kontrol Normal & $53,575 \pm 10,90^{*}$ & $229,775 \pm 23,50^{*}$ \\
CMC-Na + Parasetamol & $742,908 \pm 96,13$ & $991,075 \pm 85,74$ \\
Silimarin + Parasetamol & $115,411 \pm 14,31^{*}$ & $247,150 \pm 29,07^{*}$ \\
Dosis Ekstrak 60 mg/ Kg BB + & $240,846 \pm 11,15^{*}$ & $742,632 \pm 68,81^{*}$ \\
Parasetamol & & \\
Dosis Ekstrak $120 \mathrm{mg} / \mathrm{Kg}$ BB + & $348,036 \pm 56,79^{*}$ & $796,947 \pm 91,40^{*}$ \\
Parasetamol & & \\
Dosis Ekstrak $240 \mathrm{mg} / \mathrm{Kg} \mathrm{BB} \mathrm{+}$ & $381,137 \pm 24,69^{*}$ & $815,804 \pm 38,98^{*}$ \\
Parasetamol & & \\
\hline
\end{tabular}

Hasil pengujian pada tabel 1 menunjukkan bahwa terjadi kenaikan nilai SGPT dan SGOT pada semua kelompok perlakuan oleh induksi parasetamol. Hal ini menunjukkan adanya kerusakan atau gangguan pada fungsi hati karena pemberian parasetamol. Tabel I juga menunjukkan terjadi perbedaan yang signifikan $(\mathrm{p}<0.05)$ pada nilai SGPT dan SGOT antara perlakuan kontrol positif dibandingkan dengan kelompok kontrol negatif. Hal ini sesuai dengan hasil penelitian bahwa silimarin mampu digunakan sebagai hepatoprotektor (Saeed et al., 2017; Surai, 2015). Serum Glutamat Piruvat Transaminase (SGPT) atau juga sering disebut ALT (alanine aminotransferase) dan Serum Glutamat Oksaloasetat Transaminase (SGOT) atau sering disebut AST (aspartat aminotransferase) merupakan suatu enzim yang dapat untuk memperkirakan kerusakan suatu sel terutama organ hati (Gowda et al., 2009; Limdi and Hyde, 2003). Nilai SGPT merupakan parameter spesifik pada kerusakan hati, sementara nilai SGOT tidak spesifik sebagai parameter kerusakan hati, karena juga terdapat pada kasus infark miokardial, nekrosis otot, ginjal, otak dan hemolisis intravaskuler (Rolfes et al., 2014; Talwar dan Srivastava, 2002). 
Kelompok ekstrak dosis 60, 120, dan $240 \mathrm{mg} / \mathrm{kgBB}$ mampu mencegah kenaikan SGPT dan SGOT secara signifikan $(\mathrm{p}<0.05)$ dibandingkan dengan kelompok kontrol negatif. Ekstrak etanol daun karika diketahui mempunyai kandungan senyawa flavonoid, alkaloid, tanin dan fenol (Laily et al., 2012). Senyawa tersebut telah diketahui memiliki aktivitas sebagai antioksidan (Indranila dan Ulfah, 2017; Mu'awwanah dan Ulfah, 2017). Aktivitas antioksidan inilah disinyalir berhubungan dengan aktivitas hepatoprotektif pada ekstrak daun karika (Jain et al., 2008; Oh et al., 2004; Videla, 2009). Radikal bebas reaktif melakukan kerusakan sel melalui dua mekanisme utama yaitu ikatan kovalen dan lipid peroksidase. Proses lipid peroksidase telah ditunjukkan untuk meningkatkan sintesis kolagen dan fibrosis. Oleh karena itu, antioksidan dapat berperan dalam menghambat kerusakan hati yang diinduksi selama kerusakan sel (Slater, 1988).

\section{Kesimpulan}

Hasil penelitian diketahui bahwa ekstrak etanol daun karika (Vasconcellea pubescens A.DC.) berpengaruh pada penurunan kadar SGPT dan SGOT pada tikus jantan galur Sprague Dawley yang diinduksi parasetamol pada dosis 60, 120, dan $240 \mathrm{mg} / \mathrm{kg}$ BB secara signifikan $(\mathrm{p}<0.05)$ bila dibandingkan dengan kontrol negatif.

\section{Ucapan Terimakasih}

Terimakasih kepada segenap mahasiswa dari kelompok studi Farmakologi dan Nutrasetikal Program Studi S1 Farmasi UNS.

\section{Daftar Pustaka}

Brune, K., Renner, B., dan Tiegs, G., 2015. Acetaminophen/paracetamol: A history of errors, failures and false decisions. Eur. J. Pain 19, 953-965.

Chen, M., Suzuki, A., Borlak, J., Andrade, R.J., dan Lucena, M.I., 2015. Drug-induced liver injury: Interactions between drug properties and host factors. J. Hepatol. 63, 503-514.

Chiu, P.Y., Tang, M.H., Mak, D.H.F., Poon, M.K.T., dan Ko, K.M., 2003. Hepatoprotective mechanism of schisandrin B: role of mitochondrial glutathione antioxidant status and heat shock proteins. Free Radic. Biol. Med. 35, 368-380.

Gowda, S., Desai, P.B., Hull, V.V., Math, A.A.K., Vernekar, S.N., dan Kulkarni, S.S., 2009. A review on laboratory liver function tests. Pan Afr. Med. J. 3.

Indranila, I., dan Ulfah, M., 2017. Uji Aktivitas Antioksidan Ekstrak Etanol Daun Karika (Carica pubescens) dengan Metode DPPH beserta Identifikasi Senyawa Alkaloid, Fenol dan Flavonoid. E-Publ. Fak. Farm. 0, 105-111.

Jain, A., Soni, M., Deb, L., Jain, A., Rout, S.P., Gupta, V.B., dan Krishna, K.L., 2008. Antioxidant and hepatoprotective activity of ethanolic and aqueous extracts of Momordica dioica Roxb. leaves. J. Ethnopharmacol. 115, 61-66.

James, L.P., Mayeux, P.R., dan Hinson, J.A., 2003. Acetaminophen-Induced Hepatotoxicity. Drug Metab. Dispos. 31, 1499-1506. 
Laily, A.N., Suranto, S., dan Sugiyarto, S., 2012. Characterization of Carica pubescens in Dieng Plateau, Central Java based on morphological characters, antioxidant capacity, and protein banding pattern. Nusant. Biosci. 4.

Larsen, F.S., dan Wendon, J., 2014. Understanding paracetamol-induced liver failure. Intensive Care Med. 40, 888-890.

Limdi, J.K., dan Hyde, G.M., 2003. Evaluation of abnormal liver function tests. Postgrad. Med. J. 79, 307-312.

Mu'awwanah, A., dan Ulfah, M., 2017. Uji Aktivitas Antioksidan Fraksi n-Heksan Ekstrak Etanol Daun Karika (Carica pubescens) dan Identifikasi Senyawa Alkaloid dan Flavonoidnya. E-Publ. Fak. Farm. 0, 118-124.

Novalina, D., 2013. Aktivitas Antibakteri Ekstrak Daun Carica Pubescens dari Dataran Tinggi Dieng Terhadap Bakteri Penyebab Penyakit Diare. EL-VIVO 1.

Nurrochmad, A., Margono, S.A., Sardjiman, Hakim, A.R., Ernawati, Kurniawati, E., dan Fatmawati, E., 2013. Hepatoprotective and antioxidant activity of pentagamavunon-0 against carbon tetrachloride-induced hepatic injury in rats. Asian Pac. J. Trop. Med. 6, 438-442.

Oh, H., Kim, D.-H., Cho, J.-H., dan Kim, Y.-C., 2004. Hepatoprotective and free radical scavenging activities of phenolic petrosins and flavonoids isolated from Equisetum arvense. J. Ethnopharmacol. 95, 421-424.

Reuben, A., Koch, D.G., dan Lee, W.M., 2010. Drug-induced acute liver failure: Results of a U.S. multicenter, prospective study. Hepatology 52, 2065-2076.

Rolfes, S.R., Pinna, K., dan Whitney, E., 2014. Understanding Normal and Clinical Nutrition. Cengage Learning.

Saeed, M., Babazadeh, D., Arif, M., Arain, M.A., Bhutto, Z.A., Shar, A.H., Kakar, M.U., Manzoor, R., dan Chao, S., 2017. Silymarin: a potent hepatoprotective agent in poultry industry. World39s Poult. Sci. J. 73, 483-492.

Sasongko, H., Sugiyarto, S., Efendi, N.R., Pratiwi, D., Setyawan, A.D., dan Widiyani, T., 2016. Analgesic Activity of Ethanolic Extracts of Karika Leaves (Carica pubescens) In Vivo. J. Pharm. Sci. Clin. Res. 1, 83-89.

Slater, T.F., 1988. Free Radical Mechanisms in Tissue Injury, in: Cell Function and Disease. Springer, Boston, MA, pp. 209-218.

Supono, S., 2014. Potensi Ekstrak Biji Karika (Carica Pubescens) Sebagai Larvasida Nyamuk Aedes aegypti. EL-VIVO 2.

Surai, P.F., 2015. Silymarin as a Natural Antioxidant: An Overview of the Current Evidence and Perspectives. Antioxidants 4, 204-247.

Talwar, G., dan Srivastava, L., 2002. Textbook of biochemistry and human biology. PHI Learning Pvt. Ltd.

Vakiloddin, S., Fuloria, N., Fuloria, S., Dhanaraj, S.A., Balaji, K., dan Karupiah, S., 2015. Evidences of hepatoprotective and antioxidant effect of Citrullus colocynthis fruits in paracetamol induced hepatotoxicity. Pak. J. Pharm. Sci. 28, 951-957.

Videla, L.A., 2009. Oxidative stress signaling underlying liver disease and hepatoprotective mechanisms. World J. Hepatol. 1, 72-78. 